Martin Roland

Wiedeń

\title{
Iluminowane manuskrypty w Internecie. Inwentarz rękopisów opactwa cystersów w Stams w Tyrolu (Austria)
}

Inwentarz rękopisów iluminowanych biblioteki opactwa cystersów $w$ Stams $^{1}$, który tutaj przedstawiam, jest przedsięwzięciem zespołowym. Chcę podkreślić ten fakt, gdyż praca nad nim połączyła wiele osób i różne instytucje: w pierwszym rzędzie samo opactwo w Stams jako właściciela przedstawionych rękopisów, następnie Komisję ds. Piśmiennictwa i Księgoznawstwa (Kommission für Schrift- und Buchwesen des Mittelalters, w skrócie: KSBM) Austriackiej Akademii Nauk (Österreichische Akademie der Wissenschaften, w skrócie: ÖAW $)^{2}$, reprezentowaną przez Marię Theisen, Armanda Tifa i moją osobę, a także Lilian Armstrong z Wellesley College pod Bostonem ${ }^{3}$.

Artykuł ten jest adaptacją pierwotnej wersji niemieckojęzycznej Illuminierte Handschriften im Internet. Kurzinventar der Handschriften des Zisterzienserstiftes Stams in Tirol, która się ukazała w tomie zbiorowym Die neue Bibliothek - Anspruch und Wirklichkeit; 31. Österreichischer Bibliothekartag, Innsbruck, 18. - 21, 10. 2011, hg. von Klaus Niedermair (Schriften der Vereinigung Österreichischer Bibliothekarinnen und Bibliothekare, 11), Innsbruck - Feldkirch 2012, s. 54-66.

\footnotetext{
${ }^{1}$ Kurzinventar der illuminierten Handschriften bis 1600 in der Bibliothek des Zisterzienserstiftes Stams in Tirol, 2010 [http://www.univie.ac.at/paecht-archiv-wien/ki/stams.html].

${ }^{2}$ Zob. http://www.ksbm.oeaw.ac.at [29 XI 2011]. W ÖAW trwa proces przekształceń i restrukturyzacji i jest mało prawdopodobne, że nazwa i adres KSBM, zasłużonej instytucji o długiej tradycji, pozostaną bez zmian. Jej zadania będą jednak nadzorowane przez Akademię Nauk w ramach Institut für Mittelalterforschung (por. bazy danych: http://www.manuscripta.at oraz http://www.ksbm.oeaw.ac.at/wz/wzma.php).

${ }^{3}$ A. Tif i M. Theisen współpracowali już przy tworzeniu pierwszego Inwentarza, poświęconego zbiorom klasztoru kanoników regularnych św. Augustyna w Herzogenburgu (patrz następny przypis). W obu przypadkach $\mathrm{M}$. Theisen wniosła specjalistyczną wiedzę z zakresu gotyckiego malarstwa książkowego Czech, sporządzając obszerne opisy; w Stams brała też udział w autopsji oraz fotografowaniu rękopisów. A. Tif znacznie udoskonalił
} 
Inwentarz rękopiśmiennych zbiorów znajdujących się w Stams jest już drugim przedsięwzięciem $\mathrm{w}$ ramach nowatorskiego projektu, którego celem jest prezentacja kompletnej zawartości iluminowanych rękopisów z wybranych, małych zbiorów na terenie Austrii. Jego celem jest stworzenie wyczerpującego przeglądu tych zasobów ${ }^{4}$. Inwentarz rękopisów ze Stams składa się z ogólnych informacji dotyczących samego projektu ${ }^{5}$, charakteru zbiorów i ich historii ${ }^{6}$, oraz z krótkich opisów 34 rękopisów i odnośnej dokumentacji fotograficznej (822 cyfrowe ilustracje). Nawet jeśli na temat niektórych rękopisów dostępne są aktualne i obszerne wyniki badań ${ }^{7}$, to właściwym celem takich inwentarzy nie jest kompletny opis poszczególnych zabytków i ich ostateczna klasyfikacja, lecz stworzenie przejrzystej formuły dostępu do zasobów dotąd nieznanych lub mało uwzględnianych. $\mathrm{Z}$ powodu ograniczeń narzuconych przez formułę tego działu, nie zaprezentujemy tego Inwentarza w całej złożoności jego funkcjonowania ani też wyczerpująco nie omówimy zawartych w nim cennych rękopisów ${ }^{8}$. Skoncentrujemy się natomiast na strategiach, umożliwiających skuteczne wyszukiwanie w sieci informacji w nim za-

stworzony przez nas, a przez niego zrealizowany sposób prezentacji; por. jego publikacje na ten temat: A. Tif, Low-Budget-Konzept zur Online-Inventarisierung von Kleinsammlungen [http://www.univie.ac.at/paecht-archiv-wien/ki/low-budget-konzept-zur-online-inventarisierung-von-kleinsammlungen.pdf.]; tenże, Kunsthistorische Online-Kurz-inventare illuminierter Codices in österreichischen Klosterbibliotheken, [w:] Kodikologie und Paläographie im digitalen Zeitalter 2 - Codicology and Palaeography in the Digital Age 2, Hg. Franz Fischer, Christiane Fritze, Georg Vogeler, unter Mitarbeit von Bernhard Assmann, Malte Rehbein, Patrick Sahle, Norderstedt 2010, s. 21-32 [http://kups.ub.uni-koeln.de/id/ eprint/4340]; tenże, Digitale kunsthistorische Inventarisierung mittelalterlicher Buchbestände im Web (Teil 2 von: Helga Penz, Martin Roland, Armand Tif, Klosterbibliotheken: Wer digitalisiert für wen?), [w:] 14th International Congress „Cultural Heritage and New Technologies“. Vienna, 2009, s. 67-73 [http://www.univie.ac.at/paecht-archiv-wien/dateien/Penz-RolandTif_Klosterbibliotheken.pdf]. Co się tyczy wkładu L. Armstrong, por. niżej, s. 198.

${ }_{4}^{4}$ Pierwszy Inwentarz objął zasoby klasztoru kanoników regularnych św. Augustyna w Herzogenburgu: Armand Tif, Martin Roland unter Mitarbeit von Maria Theisen und Alois Haidinger, Kurzinventar der illuminierten Handschriften bis 1600 und der Inkunabeln in der Bibliothek des Augustiner-Chorherrenstiftes Herzogenburg in Niederösterreich, Version 2 (November 2009) - http://www.univie.ac.at/paecht-archivwien/ki/herzogenburg.html. Dostępna jest również jego angielskojęzyczna wersja, przygotowana przez Kartyn Martin z University of Pitsburgh.

${ }^{5}$ Zob. Geleitwort zur kunsthistorischen Bestandsaufnahme Stams 2008 [http://www. univie.ac.at/paecht-archiv-wien/ki/stams/startseite.htm].

${ }^{6}$ Zob. http://www.univie.ac.at/paecht-archiv-wien/ki/stams/einleitung.htm

${ }^{7}$ Tu wymienić należy przede wszystkim obszerniejsze rozprawy na temat poszczególnych zabytków: rps 3 (M. Roland), rps 12 (M. Theisen) oraz rps 44 (L. Armstrong, M. Roland).

${ }^{8}$ Tutaj wskazać należy wprowadzenie do samego Inwentarza Stams (por. przyp. 5 i 6 ) oraz ogłoszony drukiem referat: M. Roland, Geheimnisse der Stiftsbibliothek im $W W W$, „Spektrum, Zeitschrift des Meinhardinums”, 2010/2011, s. 6-8 [http://www.uni- 
wartych. Głównym celem niniejszego artykułu jest zatem wyeksponowanie aspektu medialnego całego przedsięwzięcia.

\section{W jaki sposób znaleźć Inwentarz w Internecie?}

Większość użytkowników Internetu, poszukujących w sieci informacji na temat zasobu rękopisów w klasztorze Stams (założonym w końcu XIII w., położonym w dolinie górnej Iny, na zachód od Innsbrucka), wejdzie na stronę tego klasztoru (http://www.stiftstams.at/index.php) lub sprawdzi stosowny artykuł w Wikipedii ${ }^{9}$. Z internetowej strony opactwa przez zakładkę Kunst \& Kultur przejść można wprost do biblioteki klasztornej, Stiftsbibliothek. Tam znajduje się informacja o KSBM i link odsyłający bezpośrednio na stronę Inwentarza ${ }^{10}$, a nawet odnośnik do niemieckiej wersji niniejszego artykułu. Wspomniana w przypisie 10 decyzja o zmianie lokalizacji Inwentarza w Internecie spowodowała zerwanie długo budowanej sieci odsyłaczy. Od września 2011 r. jest on wprawdzie znowu dostępny przez stronę opactwa w Stams, ale zaistniały incydent pokazuje, jak nagląca staje się kwestia systemowego wyszukiwania zasobów w sieci. Tylko ten bowiem, kto zna aktualny adres URL i wpisze go poprawnie w wyszukiwarkę, może uzyskać bezpośredni dostęp do Inwentarza.

\section{Dostęp przez platformę manuscripta.at}

Wtajemniczeni dobrze wiedzą, że dostęp do zasobów opactwa Stams można też uzyskać przez bazę danych manuscripta.at, stworzoną przez Aloisa Haidingera i umieszczoną na stronie $\mathrm{KSBM}^{11}$. Od samego początku oczywiste było, że manuscripta.at mają stanowić w Internecie „jedno okienko”, wspólną witrynę, przez którą będzie można dotrzeć do

\footnotetext{
vie.ac.at/paecht-archiv-wien/dateien/roland_geheimnisse-der-stiftsbibliothek-imwww.pdf].

9 Zob. http://de.wikipedia.org/wiki/Stift_Stams (29.11.2011). Niezwykle kompetentny artykuł, nie wspominający wprawdzie o manuskryptach, ale zawierający link do Inwentarza.

${ }^{10}$ Link do Inwentarza od września 2011 roku prowadzi w próżnię, ponieważ Uniwersytet Wiedeński, z którego serwera gościnnie korzystała ta publikacja, wskutek niezbyt chyba przemyślanej akcji zawiesił stronę Otto-Pächt-Archiv, co spowodowało, że znajdujące się na niej materiały musiały otrzymać nowy adres w sieci. Zamiast więc dotychczasowego, po wielekroć podawanego w sieci adresu http://paechtarchiv/univie.ac.at/ki/ stams.html, korzystać teraz należy $\mathrm{z}$ nowego, być może również tymczasowego: http://www.univie.ac.at/paecht-archiv-wien/ki/stams.html.

${ }^{11}$ Co się tyczy tej propozycji odsyłam do artykułu Ursuli Stampfer, Tiroler Handschriften in manuscripta.at: Einblicke - Ausblicke, [w:] Die neue Bibliothek - Anspruch und Wirklichkeit; 31. Österreichischer Bibliothekartag..., s. 44-50.
} 
wszystkich zachowanych w Austrii rękopisów. Takie rozwiązanie się sprawdziło, ale z oczywistych względów może spełniać swoje zadania jedynie wobec niewielkiej grupy fachowców, którzy je znają.

\section{Dostęp przez wyszukiwarki internetowe}

Kiedy szukam czegoś konkretnego, dajmy na to incipitu jakiegoś tekstu średniowiecznego, informacji na temat autorów lub miniaturzystów itd, wtedy najpierw korzystam z wyszukiwarki internetowej. Robię to ja, wyspecjalizowany w jednej dziedzinie naukowiec, ale postępują tak na co dzień również studenci i „normalni” użytkownicy Internetu.

Kto wpisze w Google „Inwentarz” [„Kurzinventar”] i „Stams”, jako pierwszy wynik wyszukiwania otrzyma właśnie stworzony przez nas Inwentarz rękopisów. Technologia przeszukiwania zasobów pozwoliła mi odnaleźć go (po krótkiej irytacji) także w nowym miejscu w cyberprzestrzeni. Wpisanie takiej treści do wyszukiwarki zakłada jednak, że szukający już wie o istnieniu Inwentarza. Można założyć, że użytkownik wpisze w poszukiwanym polu „rękopisy”, „malarstwo książkowe”, „inicjały” czy „fleuronnée" - wszystkie one są bowiem powiązane ze „Stams”. W tym przypadku przyjmujemy, że szukający nie wiedział wcześniej o istnieniu samego Inwentarza, a opierał się tylko na przypuszczeniu, że w opactwie średniowiecznym mogą znajdować sie iluminowane rękopisy.

W każdej z tych kombinacji poszukiwań Inwentarz pojawiał się jako jedna $\mathrm{z}$ pierwszych odpowiedzi ${ }^{12}$. Poszukiwania dotyczyły rękopisów z klasztornej biblioteki, a więc zakładany stan wiedzy szukającego był porównywalny z tym, jakim dysponują użytkownicy, wchodzący na stronę Inwentarza przez stronę opactwa.

Prawdziwa korzyść z wyszukiwarek widoczna jest dopiero tam, gdzie proponują one ten Inwentarz szukającemu nie posiadającemu konkretnej, specjalistycznej wiedzy na temat tych zbiorów. Oto trzy przykłady.

Jeśli kogoś interesują prace Alberta Wielkiego (zm. 1280 w Kolonii), może wpaść na pomysł obejrzenia rękopisów, w których one występują, obiecując sobie ich wyjątkowo piękną formę. Zapytanie w wyszukiwarce o „Albertus”, „Magnus” oraz „inicjały” daje 23100 wyszukanych odpo-

12 Kolejność i porządek odpowiedzi w Google następuje nie tylko według niezależnych od użytkownika niezmiennych kryteriów, lecz uwzględnia również upodobania i zainteresowania szukających; pewne znaczenie ma także wybór konkretnej wyszukiwarki, którą się posługujemy. Z tego względu poszukiwania przeprowadzano nie tylko z komputera autora, ale także $\mathrm{z}$ innych, neutralnych miejsc i $\mathrm{z}$ wykorzystaniem innych wyszukiwarek. 
wiedzi (13 XII 2011). Te znajdujące się na pierwszych miejscach są dla szukającego niezwykle interesujące ${ }^{13}$. Podczas austriackiego Dnia Bibliotekarza (październik 2011) Inwentarz rękopisów pojawiał się na siódmej pozycji, pod koniec listopada na pozycji 15, a 13 grudnia na pozycji 10.

Dlaczego? - Pierwszy kodeks biblioteki klasztornej powstał w 1304 roku w Stams, 31 lat po założeniu opactwa przez Meinharda II z Görz (Tyrol) i 24 lata po poświęceniu klasztoru. I właśnie ten rękopis, z inicjałami zdobionymi motywami roślinnymi (fleuronnée), wykonanymi w tym klasztorze, zawiera dwa dzieła Alberta Wielkiego.

Kiedy klikam na tytuł Inwentarz [Kurzinventar], przeglądarka prowadzi mnie nie na jego stronę główną lecz na stronę z zapisem html, poświęconą temu kodeksowi (il. 1) ${ }^{14}$.

Oprócz samego tytułu Inwentarza, danych o autorach i o wewnętrznej nawigacji, w tekście znajduję sygnaturę obiektu („Stams, Stiftsbibliothek, Cod. 1”), skrócony tytuł („Albertus Magnus, Summa super missam et de sacramento altaris, De sacramento eucharistiae"), informację o lokalizacji i datacji („Stams, 1304”) oraz wyliczenie zawartych w kodeksie zdobień.

Strona ta przedstawia 35 ikon cyfrowych obrazów, dokumentujących zdobienia i inne charakterystyczne cechy kodeksu. Klikając na te ikony, uzyskujemy powiększony obraz przedstawionego obiektu. Możemy oglądać całe strony rękopisu (il. 2) lub wyszukać jakiś detal, np. inicjały na k. 52v, które - wielokrotnie powiększone - przedstawią graficzną precyzję rysownika sprzed 707 lat $(\ldots / \mathrm{ki} / \mathrm{stams} / \mathrm{cod}$ 01/ Stams_01_052vd6.jpg), ale możemy też obejrzeć starannie zatuszowane uszkodzenie pergaminu (.../ki/stams/cod_01/Stams_01_013r.jpg). Dostępne w wersji cyfrowej są oczywiście także inicjały, początki tekstów, strony z prostymi zdobieniami czy okładki, a użytkownik może sprawdzić poprawność datacji (il. 3) oraz incipity tekstów.

W ten sposób można zarówno zaspokoić naukową ciekawość, jak nasycić oczy widokiem badanych zabytków. Kto chce dowiedzieć się czegoś więcej, może kliknąć na link „Więcej informacji” i wejść do pliku PDF z opisami ${ }^{15}$. - Tutaj pozwolę sobie na uwagę na marginesie. Otóż jeśli

${ }^{13}$ Pierwsze miejsca zajmują od niedawna cyfrowe katalogi, opracowywane w ramach obszernego programu katalogowania, finansowanego przez Niemieckie Towarzystwo Badawcze (Deutsche Forschungsgemeinschaft, DFG) i dostępne obecnie przez Google-Books.

${ }^{14}$ Zob. http://www.univie.ac.at/paecht-archiv-wien//ki/stams/cod_01/cod_01.htm

15 Zob. http://www.univie.ac.at/paecht-archiv-alt/ki/stams/Kurzinventar_Stams.pdf. Tutaj znajdziemy odniesienie do datowania na fol. 132v (ale nie ma oczywiście jego cyfrowej odbitki), gdzie obok piszącego brata Rudigerusa wymieniony został także opat klasztoru w Stams, Cùnradus Walder de Faucibus, co pozwala na jednoznaczną lokalizację tego tekstu. Wymienione też są inne prace floratora, wskazujące na augsburską proweniencję jego stylu (cysterskie opactwo 


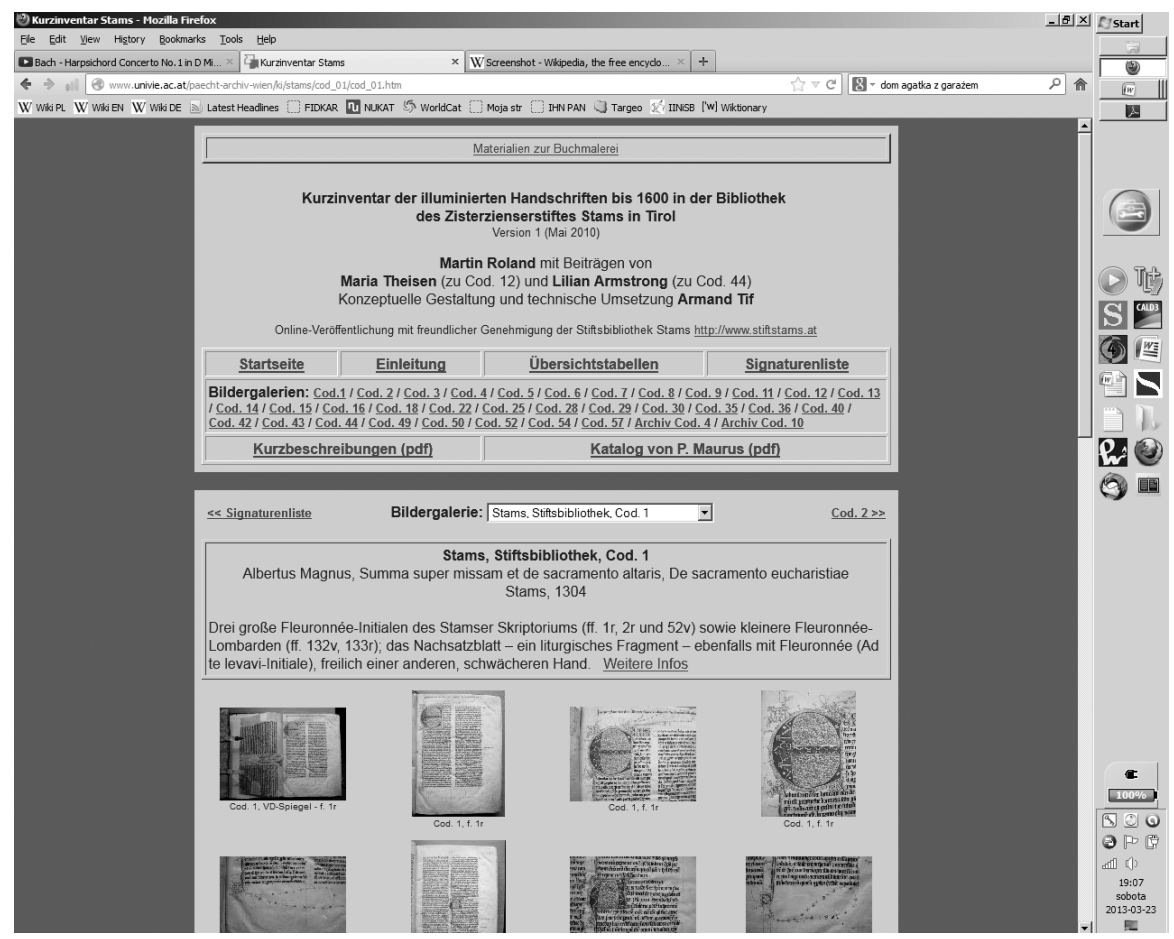

Il. 1: Inwentarz iluminowanych rękopisów ze Stams, widok ekranu przedstawiający stronę html, odnoszącą się do Cod. 1 z biblioteki klasztornej

wpiszemy do wyszukiwarki - albo mówiąc bardziej współcześnie - „wgooglujemy" - jakiś rzadko używany eksplicit, to wśród odpowiedzi na pierwszym miejscu pojawi się adres do jego prawdopodobnego wydania źródłowego ${ }^{16}$. Ten fakt może oczywiście dostrzec każdy inny użytkownik Internetu, ale w tym przypadku do poczynienia takich obserwacji trzeba najpierw wpisać odpowiednio sformułowane zapytania, a następnie właściwie ocenić odpowiedzi. Nie zmienia to faktu, że wszelkie możliwości dotarcia do tych zasobów stoją otworem przed każdym użytkownikiem Internetu i to jest dla mnie - pozwolę sobie na osobistą ocenę - największym społecznym pożytkiem z istnienia sieci.

Kaisheim k. Augsburga jest macierzystym domem Stams). Jednakże fleuronnée w tekście, który był prawdopodobnym wzorem dla tego kodeksu, nie wywodzi się z tej tradycji.

${ }_{16}$ München, Bayerische Staatsbibliothek, Clm 28.180; wyświetla się: Hermann Hauke Katalog der lateinischen Handschriften der Bayerischen Staatsbibliothek München Clm 28111-28254, Wiesbaden 1986, s. 108-110. Brzmienie eksplicitu nieoczekiwanie jest zgodne z tym z Cod.1 ze Stams (il. 1). Ponieważ ten datowany na 1281 rok kodeks pochodzi z Kaisheim, związek między nimi jest bardzo prawdopodobny, ale wymaga oczywiście szerszego niż sam eksplicit porównania obu tekstów. 
Iluminowane manuskrypty w Internecie...

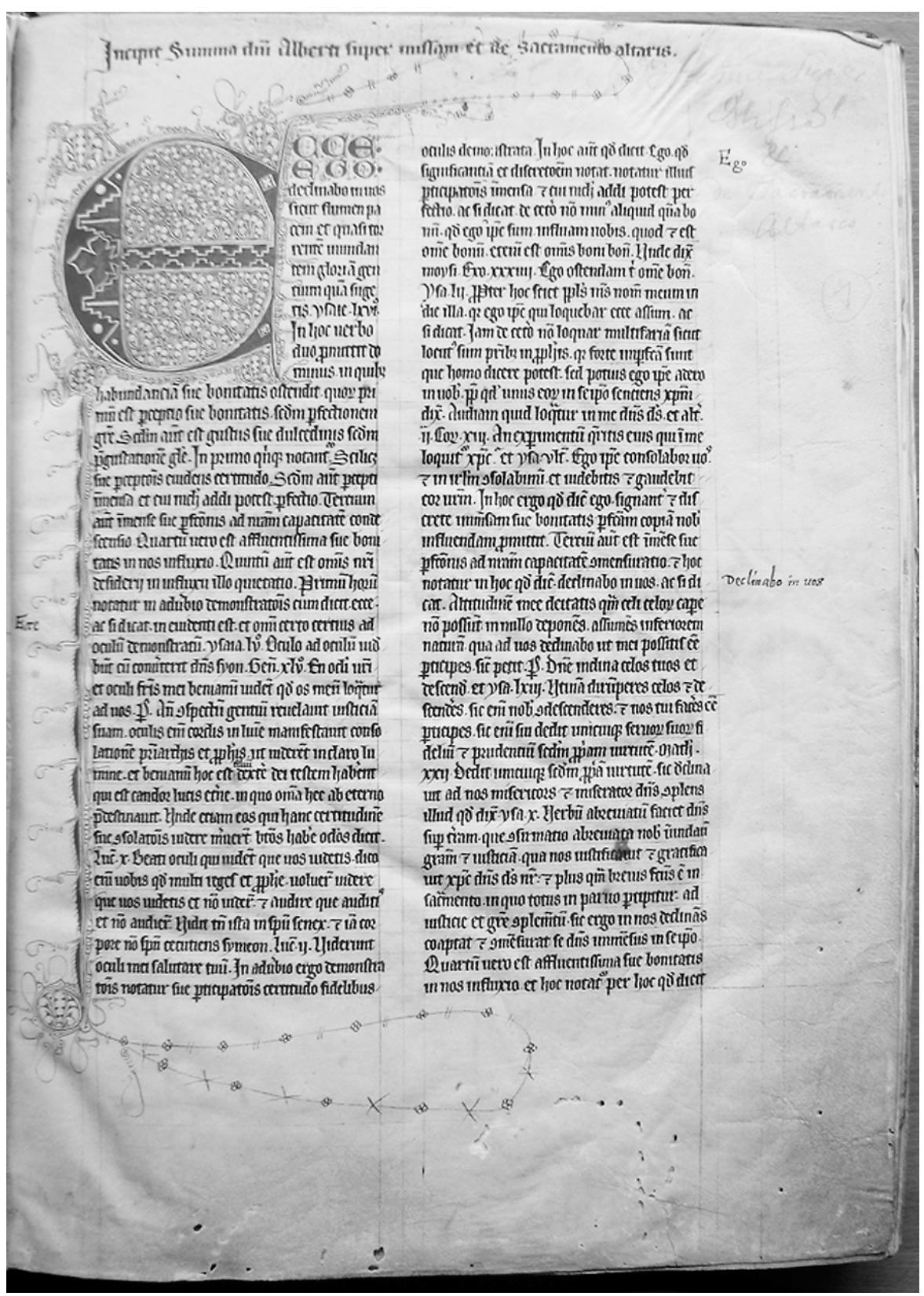

Il. 2: Stams, Biblioteka klasztorna, Cod. 1, Albert Wielki, k. 1r, początek Summa super missam et de sacramento altaris z inicjałem (fleuronnée); Stams, datacja: 1304. 


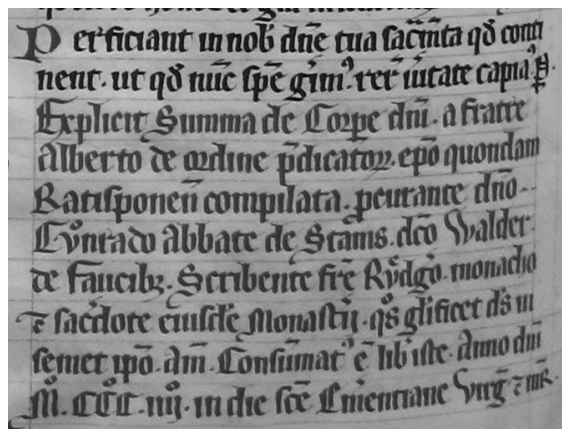

Il. 3: Stams, Biblioteka klasztorna, Cod. 1, Albert Wielki, k. 132v, datacja (1304) na końcu De sacramento eucharistiae (tu jako Summa de corpore Domini); w tym miejscu wymieniony został również pisarz, mnich ze Stams, Frater Ruedigerus, oraz opat tego klasztoru, Cùnradus Walder de Faucibus

Nie miejsce tutaj na przedstawianie wszystkich funkcji Inwentarza. Chciałbym zwrócić jeszcze tylko uwagę na listę sygnatur oraz na tabele przeglądowe z zakresu historii sztuki, do których można przejść z każdej strony Inwentarza (por. il. 1). Na liście sygnatur każdy kodeks ma swoją charakterystyczną ikonę - znacznik materiału ilustracyjnego, oraz blok tytułowy, wskazujący na informację tekstową. Kliknięcie na ilustrację albo na tekst prowadzi szukającego na odpowiednią stronę html wybranego rękopisu. Tabele dzielą całość materiału według czasu i miejsca powstania oraz według kategorii zdobień; zawierają też listę pojęć ikonograficznych. Umożliwia to konkretne i planowe poszukiwania, co stanowi główne kryterium jakościowe przy pracy naukowej z wykorzystaniem Inwentarza ${ }^{17}$.

Pierwsze zapytanie, jakie wpisujemy w wyszukiwarkę, zakłada, że robi to użytkownik zainteresowany jakimś średniowiecznym autorem. Kto wpisuje „Hans”, „Knoll”, „Bürgermeister” [burmistrz] i „Salzburg”, ten najprawdopodobniej szuka jakiejś historycznej postaci ${ }^{18}$. I chociaż to zapytanie na pierwszy rzut oka zdaje się nie mieć nic wspólnego z rękopi-

$17 \mathrm{Ta}$ indeksacja w zakresie historii sztuki, odpowiadająca w dużej mierze modelowi sprawdzonemu już w drukowanych katalogach iluminowanych rękopisów, przygotowywanych przez KSBM, stanowi wstępny etap prac mających na celu wbudowanie tych statycznych na razie stron html do bazy danych, którą można będzie przeszukiwać według kryteriów historii sztuki. Powstał już stosowny projekt w ramach wspomnianej bazy danych manuscripta.at, ale w tej chwili nie może być kontynuowany ze względu na trudności finansowe. Por. inne rozważania na ten temat: M. Roland, Wie finde ich „meinen” Buchschmuck?, wykład na warsztatach zorganizowanych przez e-codices.ch - Virtual Manuscript Library of Switzerland, Fribourg 24-25 VI 2010 - http://www.univie.ac.at/paechtarchiv-wien/ki/roland_kh-suche-fribourg.pdf (załącznik z obrazami: http://www.univie.ac.at/paecht-archiv-wien/ki/roland kh-suchefribourg ill.pdf). Zarówno ten tekst, jak wszystkie cytowane teksty A. Tifa i moje oraz liczne inne publikacje internetowe dostępne są przez stronę internetową „Materialien zur Buchmalerei“ [http://www.univie.ac.at/paechtarchiv-wien/materialien index.html].

${ }^{18}$ Hans Knoll był ostatnim osadzonym przez arcybiskupa Salzburga i pierwszym wybranym (25 I 1482 r.) burmistrzem miasta Salzburga. Burmistrzów Salzburga wymienia lista na stronie Wikipedii, którą nasza wyszukiwarka pokazuje na pierwszym miejscu (podane tam informacje są dość niedokładne). Wybór rady miejskiej i burmistrza opiera się na 


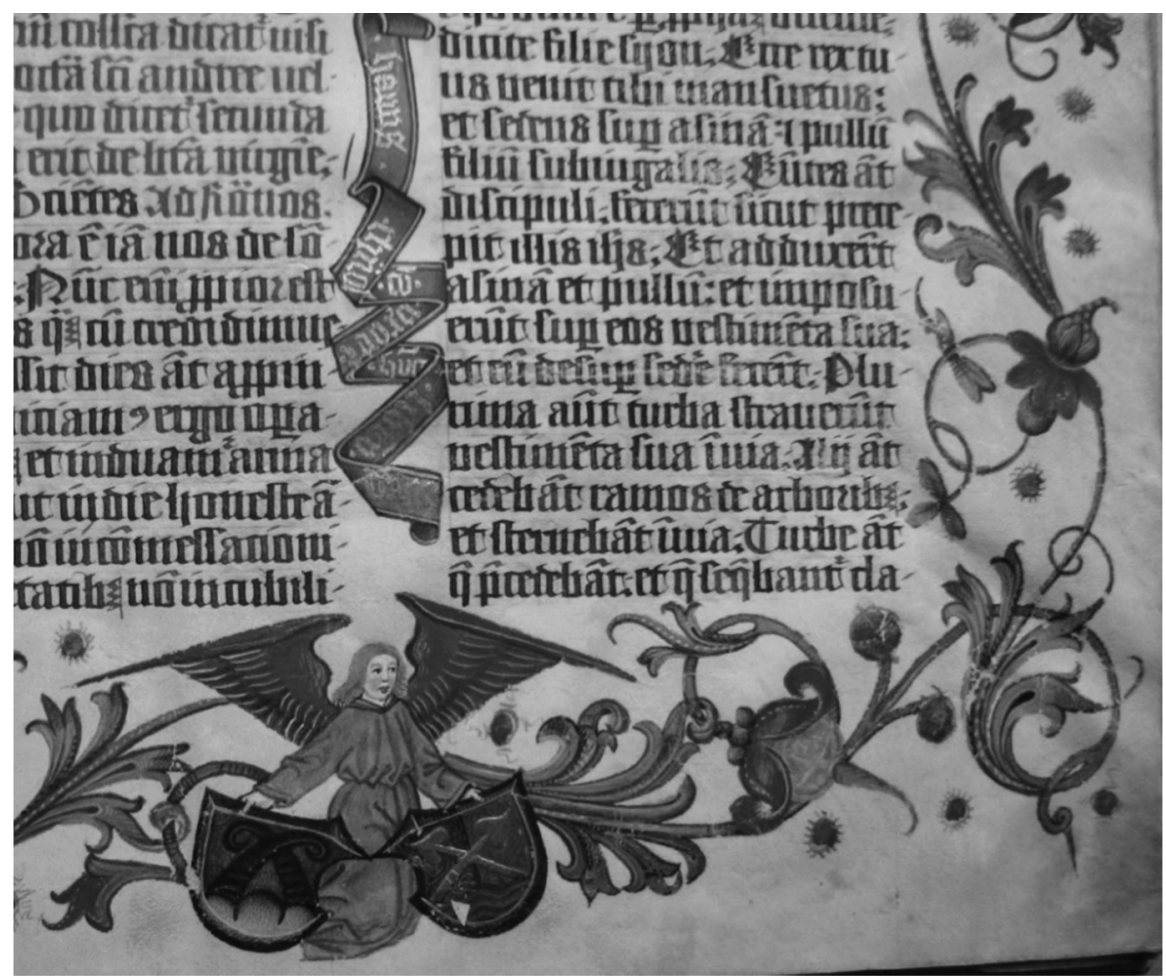

Il. 4. Stams, Biblioteka klasztorna, Cod. 3, Mszał burmistrza Salzburga Hansa Knolla i jego małżonki, fol. 1r, detal z zapisanymi złotym pismem stosownymi filakteriami i z aniołem, trzymającym herby małżonków. Salzburg, styl augsburski (salzbursko-augsburska pracownia mszałów), ostatnie ćwierćwiecze XV w.

sami, o Inwentarzu rękopisów ze Stams nie wspominając, to pojawia się on na siódmej pozycji wśród podanych 41800 odpowiedzi (13 XII 2011).

I jest to jak najbardziej na miejscu, bowiem Cod. 3 z biblioteki w Stams prezentowany jest jako „Mszał burmistrza Salzburga Hansa Knolla i jego małżonki”. Karta 1r zawiera najstarsze świadectwo herbu rodziny Knollów, jednoznaczny napis na filakterii (il. 4) oraz historyzowane zdobienia książkowe pochodzące z pracowni, która rozpropagowała panujący w Augsburgu styl na cały obszar wschodnich Alp i przede wszystkim na arcybiskupstwo salzburskie.

przywileju nadanym przez Fryderyka III Habsburga 8 XI 1481 r. (tzw. Großer Ratsbrief), natomiast same wybory odbyły się 25 I 1482 roku (a więc dopiero w 1482, a nie w 1481, jak często można przeczytać). Por. Heinz Dopsch, Peter M. Lipburger, Die rechtliche und soziale Entwicklung, [w:] Vorgeschichte - Altertum - Mittelalter, Hg. H. Dopsch (Geschichte Salzburgs, Hg.: H. Dopsch, H. Spatzenegger, I), Salzburg 1983, Teil 2, s. 733, 735. 
Wyszukiwarki stanowią też dodatkową pomoc w zakresie historii sztuki. Kto wpisze w wyszukiwarkę „Pico Meister” (w cudzysłowie), na siódmej pozycji (na ogólną ich liczbę 53, dane z 13 XII 2011) pojawi mu się odnośnik do Cod. 44 biblioteki w Stams ${ }^{19}$. Pierwsza odpowiedź to artykuł w Wikipedii na ten temat. Zakładam, że każdy bezstronny użytkownik kliknie na niego w pierwszej kolejności. A to w nim właśnie na ważnym miejscu znajduje się odsyłacz do rękopisu ze Stams i do omawianego tutaj Inwentarza ${ }^{20}$.

Cyberprzestrzeń łączy sieć tak doskonała, że nie muszę klikać wprost na nazwę naszej wirtualnej propozycji (która znajduje się na liście trafnych odpowiedzi), by zostać doprowadzonym do Inwentarza.

Inwentarz rękopisów ze Stams zdecydowanie wzbogaca istniejącą wiedzę na temat postaci „Mistrza od Pica”, ponieważ po raz pierwszy udostępnia odbiorcom ilustracje jego prac. Pięćdziesiąt trzy cyfrowe obrazy przedstawiają kalendarz z ważnymi dla lokalizacji wpisami, teksty, wpisy datacyjne i oczywiście bogatą szatę plastyczną (por. też il. 5). Przede wszystkim jednak opis katalogowy autorstwa profesor Lilian Armstrong z Wellesley College pod Bostonem prezentuje obszerną naukową klasyfikację godzinek. Wiedząc, że już Hermann Julius Hermann połączył ten mały kodeks z renesansowym malarstwem książkowym w Ferrarze ${ }^{21}$, nawiązaliśmy kon-

${ }^{19}$ Jeśli szukamy przez Google, to dominować będą odpowiedzi dotyczące Cod. 44 ze Stams. Jeśli wpiszemy do wyszukiwarki to hasło bez cudzysłowu, otrzymamy najpierw odpowiedzi na temat wkrętarki do śrub, oznaczonej jako „Meister i-drill Pico”, na siódmej pozycji inkunabuł zdobiony przez Mistrza od Pliniusza Pica Della Mirandoli z Zentralbibliothek w Zurychu, a na dziewiątym albo dziesiątym miejscu (z podanych 50000 obrazów) dwie strony z Godzinek ze Stams (13 XII 2011).

${ }^{20}$ Ten niezwykle kompetentny artykuł został stworzony przez laika ("Beatus61"; por. http://de.wikipedia.org/wiki/Benutzer:Beatus61) i umieszczony w Wikipedii 18 VI 2011. Hobby tego autora stanowi wprowadzanie do Wikipedii „nazwisk”, nadawanych anonimowym artystom od ich głównych dokonań - takich jak Mistrz od Pica (nazwany tak od rękopisu Pliniusza w zbiorach Pico della Mirandoli). Siedmiu kolejnych autorów poprawiało ten tekst. Sam Beatus61 od 23 VIII 2009 roku napisał w Wikipedii (jeśli moje przybliżone rachuby są trafne) łącznie około 753 artykułów, dotyczących głównie malarstwa (książkowego) i rzeźby. Stworzona w roku 2006 lista ich imion w Wikipedii zawiera już 832 wpisy (w tym 246, które proponują tematy do opracowania). Jako pełnoetatowy pracownik naukowy odczuwam potrzebę wyrażenia swojego szacunku wobec zapału i fachowości tego nieznanego kolegi, nie związanego zawodowo z tą problematyką.

${ }^{21}$ Hermann Julius Hermann, Zur Geschichte der Miniaturmalerei am Hofe der Este in Ferrara, „Jahrbuch der kunsthistorischen Sammlungen des Allerhöchsten Kaiserhauses” 21:1900 [http://digi.ub.uni-heidelberg.de/diglit/jbksak1900/0122], s. 239 (Wenecja, Biblioteca Marciana, II, 60, il. 104); tenże, Die illuminierten Handschriften in Tirol (Beschreibendes Verzeichnis der illuminierten Handschriften in Österreich 1, hg. Franz Wick-hoff), Leipzig 1905 [http://www.archive.org/details/DieIlluminiertenHandschriftenInTirol], s. 243-246 (wykonany przez niemieckiego pisarza i miniaturzystę, wywodzącego się z górnej Italii [a może z Ferrary?] w roku 1482, prawdopodobnie w Brixen [albo przynajmniej 


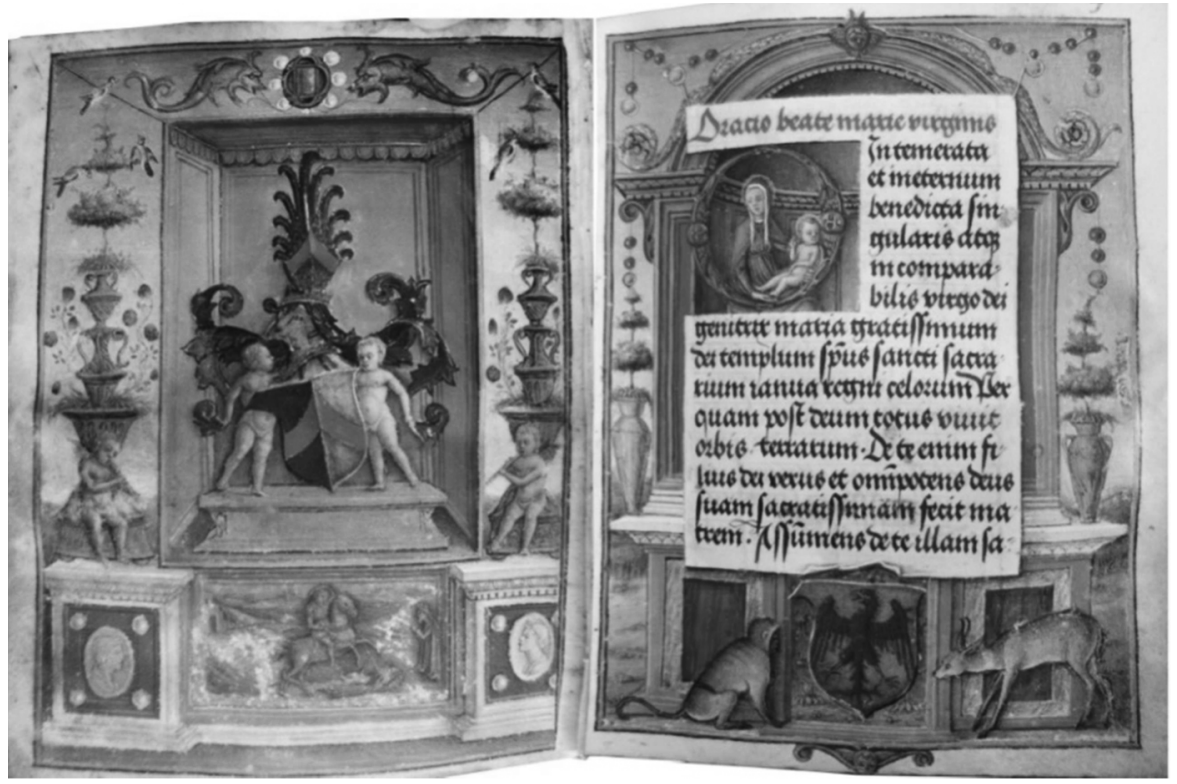

Il. 5. Stams, Biblioteka klasztorna, Cod. 44, Godzinki Ulricha Kneußla, montaż: po lewej fol. Ir (lustrzane odbicie strony) z herbem Kneußla, a po prawej k. 5r z początkiem modlitwy $O$ Intemerata z godłem Trydentu (Kneußl był kanonikiem katedralnym w Trydencie), koczkodanem i kozicą. Zdobienia wykonane przez czynnego w Wenecji „Mistrza od Pica”, datowane na 1482 rok.

(Ta ilustracja ma również uświadomić, jak wielkie możliwości podrabiania dzieł sztuki otwiera dygitalizacja obrazów. Praktyki fałszowania są częste i - choć nie w tym stopniu, jak pokazujemy tym montażem - codziennie stosowane.)

takt z panią Lilian Armstrong, niezwykle kompetentną znawczynią renesansowego malarstwa książkowego w Wenecji, gdzie przede wszystkim pracował „Mistrz od Pica”. Dzięki udziałowi pani Profesor w katalogowaniu Cod. 44 nasz Inwentarz stał się ważną publikacją również w tym zakresie.

\section{Podsumowanie}

Inwentarze iluminowanych rękopisów pomyślane zostały jako propozycja dla wszystkich użytkowników Internetu. Szybko okazało się, że cieszą się nieoczekiwanie dużym powodzeniem ${ }^{22}$. Rękopisy średniowieczne

w diecezji Brixen]; wymieniony wyżej rękopis z Biblioteki Marcjańskiej w Wenecji został przywołany dla porównania stylu). Obie publikacje są także dostępne online.

22 Dawny portal internetowy Archiwum Ottona Pächta (Otto-Pächt-Archiv) regularnie odwiedzali użytkownicy 1000-1200 komputerów (total unique sites - ca. 2500 visits 6000-8000 pages). We wrześniu 2010 r., kiedy prezentowany był Inwentarz rękopisów ze 
stanowią wdzięczny materiał dla prezentacji internetowych, w których ważną rolę odgrywają ilustracje, gdyż przechowywane w bibliotekach i pilnie strzeżone oryginały są stosunkowo trudno dostępne. Inwentarze wchodzą w skład „Materiałów dotyczących malarstwa książkowego” (http://www.univie.ac.at/paecht-archiv-wien/materialien_index.html), które prezentują również inne dostępne online efekty prac naukowych historyków sztuki, współpracujących z Komisją Piśmiennictwa i Księgoznawstwa oraz Archiwum Ottona Pächta (Otto-Pächt-Archiv).

tłum. Agnieszka Gadzała

Stams, było ich aż 3655. „Materialien zur Buchmalerei” [http://www.univie.ac.at/paechtarchiv-wien/materialien_index.html], gdzie znajdują się obecnie oba Inwentarze, w listopadzie 2011 roku miały wskutek zmiany adresu URL (por. przyp. 10) zaledwie po 500 wejść z różnych komputerów (800-1600 visits - 2000-4000 pages). Wzrostowa tendencja, jaka stale utrzymuje się od września, pozwala na uzasadniony optymizm, że nowa marka pod nazwą „Materialien zur Buchmalerei” będzie systematycznie umacniała swoją pozycję dzięki dużej liczbie oferowanych możliwości oraz dzięki miejscu, na którym pojawia się wśród wyszukiwanych odpowiedzi. W każdym razie przy wyszukiwaniu „Materialien” i „Buchmalerei” strona ta wskazywana jest jako trzecia wśród ponad miliona szacowanych odpowiedzi (13 XII 2011). Na pierwszym miejscu znajduje się artykuł w Wikipedii, zatytułowany „Buchmalarei”, na drugim zaś „Glossar zur spätmittelalterlichen Buchmalerei und Buchherstellung“, udostępniany przez Bibliotekę Uniwersytecką w Heidelbergu. 